\title{
Emancipation or Accommodation?
}

\section{Habermasian vs. Rawlsian Deliberative Democracy}

Rostbøll, Christian Fogh

Published in:

Philosophy \& Social Criticism

DOI:

10.1177/0191453708093083

Publication date:

2008

\section{Document version}

Early version, also known as pre-print

Citation for published version (APA):

Rostbøll, C. F. (2008). Emancipation or Accommodation? Habermasian vs. Rawlsian Deliberative Democracy. Philosophy \& Social Criticism, 34(7), 707-736. https://doi.org/10.1177/0191453708093083 


\title{
Philosophy \& Social Criticism
}

http://psc.sagepub.com

\section{Emancipation or accommodation?: Habermasian vs. Rawlsian deliberative democracy}

Christian F. Rostbøll

Philosophy Social Criticism 2008; 34; 707

DOI: $10.1177 / 0191453708093083$

The online version of this article can be found at:

http://psc.sagepub.com/cgi/content/abstract/34/7/707

\author{
Published by: \\ (S)SAGE Publications \\ http://www.sagepublications.com
}

Additional services and information for Philosophy \& Social Criticism can be found at:

Email Alerts: http://psc.sagepub.com/cgi/alerts

Subscriptions: http://psc.sagepub.com/subscriptions

Reprints: http://www.sagepub.com/journalsReprints.nav

Permissions: http://www.sagepub.com/journalsPermissions.nav 


\title{
Christian F. Rostbøll
}

\section{Emancipation or accommodation?}

\section{Habermasian vs. Rawlsian deliberative democracy}

\begin{abstract}
The development of the theory of deliberative democracy has culminated in a synthesis between Rawlsian political liberalism and Habermasian critical theory. Taking the perspective of conceptions of freedom, this article argues that this synthesis is unfortunate and obscures some important differences between the two traditions. In particular, the idea of internal autonomy, which was an important, implicit idea in the ideology critique of the earlier Habermas, falls out of view. There is no room for this dimension of freedom in political liberalism and it has largely disappeared from the later Habermas. In so far as others have followed Rawls and Habermas, deliberative democratic theory has converged around a less critical and more accommodationist view of freedom. If we want to keep deliberative democracy as a critical theory of contemporary society, we should resist this convergence. Our starting point should not be 'the fact of reasonable pluralism' but rather 'the fact of unreflective acquiescence'. This article argues for incorporating internal autonomy in a complex theory of freedom to which deliberative democracy should be normatively committed.
\end{abstract}

Key words autonomy $\cdot$ deliberative democracy $\cdot$ freedom $\cdot$ Jürgen Habermas $\cdot$ ideology critique $\cdot$ John Rawls

The writings of Jürgen Habermas and John Rawls are the two main contemporary sources of inspiration for theorists of deliberative democracy. ${ }^{1}$ Most deliberative democrats draw on the works of one or both of them. ${ }^{2}$ Indeed, the development of the theory of deliberative democracy has culminated in a synthesis between Rawlsian political liberalism and Habermasian critical theory. This article argues that this is unfortunate, because it obscures some fundamental differences between the

PHILOSOPHY \& SOCIAL CRITICISM • vol 34 no 7 • pp. 707-736

Copyright (C) 2008 SAGE Publications (Los Angeles, London, New Delhi and Singapore) 
two traditions. Although Rawlsians and Habermasians discuss some disagreements, these are seen as remaining 'within the bounds of a family quarrel'. ${ }^{3}$ I believe that the disagreements are actually rooted in a more fundamental difference between the two traditions, a difference that lies in their distinct normative commitments and emphases with regard to dimensions of freedom. Generally speaking, Rawls' view of freedom is indebted to a liberal tradition of toleration or accommodation (going back to Locke and Madison), while Habermas' stems from a critical tradition, in the lineage of Kant and Marx, ${ }^{4}$ that views freedom as a matter of enlightenment and emancipation from all forms of oppression, including those forms that originate from false consciousness. ${ }^{5}$ These different conceptions of freedom inform two very different understandings of the role and aim of deliberation: one of accommodating people with irreconcilable views and another of deliberation as a matter of learning and emancipation.

In their 1995 discussion, ${ }^{6}$ Habermas and Rawls identified freedom as an issue they disagree on. However, this discussion focused on modern versus ancient liberties, or negative versus political freedom. ${ }^{7}$ Habermas criticizes Rawls for over-emphasizing the negative liberties at the expense of public autonomy, while Rawls criticizes Habermas for doing the opposite. ${ }^{8}$ Deliberative democrats have concentrated on reconciling these two dimensions of freedom only. ${ }^{9}$ But this is insufficient. An important part of the critical edge of the theory of deliberative democracy is that it problematizes the status of the preferences people happen to have. It does not regard preferences and interests as brute facts that uncritically can serve as input to legitimate democratic decision-making. ${ }^{10}$ The reconciliation misses an important third dimension of freedom that concerns the free formation of individual opinions, or internal autonomy. I argue that it is this dimension of freedom that distinguishes Habermas from Rawls, and that this dimension of freedom implicitly informs their discussion of individual and political freedom. This third dimension of freedom needs to be thematized and integrated with discussions of the other two.

Indeed, in his later writings Rawls moves closer to the idea of freedom as merely a matter of living in accordance with one's individually determined comprehensive doctrine, while Habermas has distanced himself from the radically emancipatory view of freedom, and especially from his roots in the critical theory tradition of ideology critique (Ideologiekritik). In so far as others have followed the two, deliberative democratic theory has converged around a less critical and more accommodationist view of freedom. I shall show that, appearances notwithstanding, there remain some crucial divergences between Rawls and Habermas. I further argue that theories of deliberative democracy should resist moving too close to the accommodationist pole. ${ }^{11}$ 
The divergences between the two traditions also reveal an unresolved tension in theories of deliberative democracy. There is a tension between the heritage of ideology critique, with its concern for emancipation from false consciousness, and the heritage of toleration liberalism, with its concern for letting people decide for themselves what constitutes the good life and the sources of morality. I see this as a tension between two dimensions of freedom, between the free and rational formation of individual beliefs (or internal autonomy), and negative freedom. Resolution of this tension requires a systematic exploration of the multiple dimensions of freedom to which deliberative democracy should be normatively committed. The challenge is to develop a more comprehensive theory of freedom that, where possible, integrates the different dimensions and, where integration is not possible, elucidates the conflicts. ${ }^{12}$

This article makes explicit the fundamental difference between the two traditions in terms of their views of freedom and autonomy and discusses whether they can and should be combined. My aim is thus both interpretative and normative. The first section makes explicit the dimension of freedom that is prioritized by the Rawlsian diagnosis of contemporary society as characterized by 'the fact of reasonable pluralism'. The second section contrasts Rawlsian and Habermasian views of reasonableness and argues that these express different dimensions of freedom. In the third section, I focus on Habermasian versions of deliberative democracy, particularly in order to argue that deliberative democrats should not sever their roots in critical theory and ideology critique.

\section{Rawls: the accommodation of reasonable doctrines and negative freedom}

The focus on toleration and accommodation is a relatively recent development related to the Rawlsians' discovery of 'the fact of reasonable pluralism'. Rawls himself characterizes the main difference between his 1971 A Theory of Justice and his 1993 Political Liberalism as an adjustment for this fact. ${ }^{13} \mathrm{~A}$ society characterized by reasonable pluralism is one in which the citizens hold irreconcilable but reasonable comprehensive doctrines; that is, they hold irreconcilable views about metaphysics, the meaning of life, the sources of morality, and the like. ${ }^{14}$ Reasonable pluralism is central to the Rawlsian view not only because of the fact that citizens hold different views of the good life. The aim is not merely to take us beyond a classical, perfectionist political philosophy of the good life to a Kantian, neutralist one that recognizes that people have different ideas about what constitutes human happiness or fulfillment. Reasonable pluralism refers to a more fundamental disagreement, one that concerns both issues of the good life and the reasons behind the 
norms that guide citizens' common life. ${ }^{15}$ This fundamental disagreement is not seen as a regrettable fact, which citizens can overcome through enlightenment or learning. Rather, 'it is a permanent feature of the public culture of democracy' (PL 36).

Rawls regards the fundamental challenge of contemporary society as one of accommodating citizens who hold different world-views. '[T] problem of political liberalism is: How is it possible that there might exist over time a stable and just society of free and equal citizens profoundly divided by reasonable though incompatible religious, philosophical, and moral doctrines?' (PL xviii). Political liberalism takes citizens' doctrines as being beyond challenge; it 'does not attack or criticize any reasonable view' (PL xix). ${ }^{16}$ Note that political liberalism does not criticize in its role as a theory; it is not a critical theory in relation to comprehensive doctrines. In so far as the function of political philosophy is concerned, Rawls' premise is the idea of applying 'the principles of toleration to philosophy itself', which entails leaving it 'to citizens themselves to settle the questions of religion, philosophy, and morals in accordance with views they freely affirm' (PL 154). And by leaving citizens to decide for themselves, Rawls means non-publicly, not democratically or intersubjectively.

This places us squarely on the terrain of toleration or Reformation liberalism. ${ }^{17}$ By toleration liberalism, I mean a liberalism whose main concern is to accommodate citizens who hold different and irreconcilable views. Its primary normative commitment is the protection of the negative liberty to live according to one's own ideas. This liberalism has been contrasted with a liberalism whose central ideal is autonomy, and is connected to the Enlightenment project. ${ }^{18}$ Rawls explicitly denies that political liberalism belongs to the latter project (PL xviii). ${ }^{19}$ According to political liberalism, people should be left to themselves with their comprehensive views even (apparently) if they hold them non-autonomously.

Neither Rawls nor Joshua Cohen believes reasonable pluralism is defective, that it is something citizens should attempt to overcome. It should not, for example, be seen as a result of oppression and therefore 'remediable' by emancipation. Rather, it is a product of what Rawls calls the 'burdens of judgment' (PL 54ff.). ${ }^{20}$ Judgment of both theoretical and practical issues is so complex that even reasonable people are unlikely to reach the same conclusions. For Rawls, negative liberty is grounded in the fact that even perfectly reasonable and rational citizens will disagree on many fundamental issues. Thus, he says, 'reasonable persons see that the burdens of judgment set limits on what can be reasonably justified to others, and so they endorse some form of liberty of conscience and freedom of thought' (PL 61; emphasis added). There is no expectation that the divisions resulting from the burdens of judgment will be overcome; the aim is to answer how justice is possible for citizens 'who 
remain profoundly divided' (PL 4; emphasis added). There is a clear Madisonian strand here. According to Rawls, reasonable pluralism is 'the inevitable long-run result of the powers of human reason at work within the background of enduring free institutions' (PL 4, cf. 37). Like Madison's factions, the price of defeating comprehensive doctrines is the violation of negative freedom, a cure worse than the disease. ${ }^{21}$ Rawls' focus, though, unlike Madison's, is not on interest groups but on ideological-cultural groups, paradigmatically religious groups. ${ }^{22}$

Rawls argues that the fact of reasonable pluralism should result in our acceptance not only of the idea that people decide on issues concerning their private life individually, but also that 'citizens individually decide for themselves in what way the public political conception [of justice] all affirm is related to their own more comprehensive views' (PL 38). This means we are also prohibited from criticizing how others come to hold their particular political views. For by 'individually deciding', Rawls is saying more than that the individual should be the final judge of her or his political views; he is saying that citizens should have no public discussion whatsoever at the comprehensive level. ${ }^{23}$

In terms of the relationship between the different dimensions of freedom, there are two remarkable features of Rawls' view. First, the negative dimension of freedom is clearly given pride of place. Second, reasonable citizens are seen as willing to submit their comprehensive views and life-plans to the overarching idea of respect for the equal negative liberty of everyone else. It is unclear either what the source of this respect is, or why respect should have priority over any one comprehensive view. Insight into this cannot be gained from public deliberation, for in Rawls' view reasonable pluralism means that citizens already agree on certain fundamentals (such as respect), that they are reasonable from the start, and only refer to presently held beliefs. A person who observes the disagreement that results from the burdens of judgment is given no reason why this should lead him or her to accept the norm of equal negative liberty rather than force everyone else to live according to his or her preferred comprehensive view. Furthermore, he or she would have no way of knowing the exact boundaries of negative liberty. In order for a norm such as respect for the equal negative liberty of everyone to have precedence over our other commitments and aims, the overriding epistemic authority of that norm needs to be identified. But the focus on reasonable pluralism does not allow for such an epistemic authority that can trump the other aspects of reasonable comprehensive doctrines. $^{24}$

In political liberalism, negative freedom is disconnected from other dimensions of freedom. It is detached from freedom as the gaining of insights regarding the norms that regulate our common interaction. The acceptance of negative freedom and the determination of its bounds are 
not seen as products of learning, but as given premises. Moreover, negative liberty is disconnected from freedom as collective self-determination, since negative liberty is seen as a constraint on, rather than a product of, the common process of deliberation that ought to be the basis of political decision-making.

Rawls' view of the challenges facing modern society entails a conception of freedom that excludes the possibility that freedom could be augmented if fundamental ideas were discussed and criticized. Or more precisely, this is true of freedom in the political sense - which is not the same as political freedom, but is freedom as a specifically political, as opposed to comprehensive, value. In other words, from the perspective of a political conception of justice, freedom cannot refer to the process of the free formation of comprehensive views. On the contrary, the Rawlsian conception of freedom prevents the thematization of this dimension of freedom. Internal autonomy is outside the field of political philosophy (and beyond the idea of public reason, as we shall see). This reveals the clear link between the Rawlsian view and the tradition of negative freedom. ${ }^{25}$ According to political liberalism, citizens' comprehensive views are off-limits to politics. Since they are the products of freedom, it would be a violation of freedom to criticize them. So people's views of truth and morality are a non-public matter protected by a principle of toleration or negative freedom. The dimension of freedom that is off-limits as a result of this point of departure common to Rawlsian deliberative democrats concerns the free formation of fundamental views. The focus on reasonable pluralism leads to a priority of negative freedom over free opinion formation or internal autonomy. In short, it provides for a one-dimensional view of freedom.

In sum, the conception of freedom underlying political liberalism implicitly assumes that all interaction, and especially interaction in the political sphere, is a threat to freedom. It thereby obscures the distinction between free and non-coercive interaction, on the one hand, and violent and manipulative interference, on the other. It is therefore unsuitable as a conception on the basis of which we can see public deliberation as an exercise of freedom. To understand public deliberation properly, we must make the distinction obscured by negative liberty theorists. When we deliberate, there is a sense in which we interfere with one another, but we do not force one another to do anything. The freedom of the deliberative process cannot be understood in purely negative terms, since it requires the presence of and interaction with others. It does, however, include a negative element, since it must be free from force and manipulation. ${ }^{26}$ 
Rostbøll: Emancipation or accommodation

\section{Public reason and reasonableness}

Public reason is the idea that (ostensibly) connects Rawls' political liberalism to the theory of deliberative democracy. I shall discuss the idea of public reason in relation to the concomitant idea of reasonableness. Rawlsian deliberative democrats begin with reasonable pluralism, not merely pluralism. I suggest that the Rawlsian understanding of reasonableness exemplifies and exhibits an important difference to Habermasian critical theory in terms of freedom. This difference lies behind the divergent ideas of content reasonableness and form reasonableness.

\section{Content reasonableness}

Content reasonableness entails a constraint on what is an admissible content of contributions to public deliberation. In general, Rawlsians favour such a constraint, while Habermasians reject it. ${ }^{27}$ There are two parts to Rawls' own understanding of content reasonableness. First he says that the reasons we offer for political actions must be such that we 'reasonably think that other citizens might also reasonably accept those reasons' ${ }^{28}$ Then he suggests that such reasons are those that refer to 'a family of political conceptions of justice'. ${ }^{29}$ Comprehensive views, which are any reference to the whole truth, are excluded from public reason. Moreover, anything controversial is also excluded. In public deliberation, 'we are to appeal only to presently accepted beliefs' (PL 224). Reasonable pluralism and the burdens of judgment constitute the background and justification for this requirement (PL 58f.). Because people cannot agree on issues of truth, they should stick to political values and tolerate different views. By not appealing to the whole truth, citizens recognize one another's comprehensive views as reasonable, if mistaken (PL 127).

I have several objections to content reasonableness as a constraint on deliberation. At the most general level, content reasonableness undermines the very point of common deliberation, because it sets reasonableness as a pre-deliberative constraint and not as a product of deliberation. In many ways it is difficult to see Rawls' idea of public reason as an ideal for a process of public deliberation at all. Rawls' notion of public reason does not rely on the resources intrinsic to public deliberation as a dialogical process of reaching reasonable outcomes. There is no taking into account that citizens need to hear what others have to say before they can know what is reasonable. The assumption is that citizens know prepolitically what might count as reasonable arguments and outcomes. But then there is no need for any actual processes of exchanging information and reasons. ${ }^{30}$ All that is required of citizens is that they make arguments that they believe others can accept as reasonable persons. This might involve private or internal deliberation, but it does not 
require a public process of forming one's opinions in light of what others have to say.

There is an interesting parallel to Jean-Jacques Rousseau in the requirements of public reason, a parallel which Rawls himself acknowledges (PL 219f.). In On the Social Contract, Rousseau asks citizens to vote, not in accordance with what they want, but in accordance with what they think the general will is. ${ }^{31}$ If the vote were to take place after a process of public deliberation in which all have learned what the others think, I would have no objections. But for Rawls, public reason is about voting for what one thinks others would also find reasonable. Moreover, since people are prohibited from expressing what they need and want, there is no way to learn about others' needs, interests, and desires. All we get from the voting according to public reason is an aggregation of what various citizens believe might be acceptable to each other. But the point of deliberation cannot be to abstract from the needs, interests, and opinions people actually have. Rather, the purpose should be to learn these things in order to figure out which need- and interest-claims have merit and what opinions are backed by good reasons. The aim of deliberation should not be to reject partial views or egoistic interest tout court, but to screen out those that cannot be justified or generalized in a process of public deliberation. ${ }^{32}$

A primary problem with the content reasonableness constraint is that it does not consider deliberation as a process; a process that when stylized can be seen as involving stages of (1) presentation of information, claims, ideas, and opinions; (2) arguments pro and con; and (3) agreement or decision-making. It is not necessary that claims and new ideas be reasonable in the presentation stage - we often cannot know whether claims and new ideas are reasonable until we have heard what others have to say. What matters is that the final decisions are reasonable and acceptable to all. When deliberation is not seen as a process, then its value as a form of learning also falls out of sight. And in order to see the full significance of public deliberation, we should see it as a learning process. Before I enter the deliberative process, I do not know what others think and want, or what I exactly think and want. And, essentially, we do not know what we would want to do together. When we first enter the deliberative process, we cannot know what others would find reasonable and legitimate. All these are things we learn in the process of deliberation, by speaking and listening to others, by presenting our needs, interests, and opinions, by finding reasons that we learn whether others can accept, by raising objections to reasons we cannot accept, and so on. Those reasons that survive a non-distorted deliberative process are reasonable and acceptable.

The lack of concern for deliberation as a learning process can fruitfully be connected to a lack of normative commitment to freedom as 
internal autonomy or freedom as the opportunity to form one's political opinions on the basis of the best available information and reasons. The former can also be seen as neglect of a certain aspect of political autonomy, namely that if citizens are to rule themselves they must first ascertain what they really want, both individually and collectively.

There are some further implications regarding freedom that can be drawn from the way Rawls construes content reasonableness. These can be seen from two different angles: one regards which view of freedom is taken as the point of departure, the other regards what citizens hope to achieve from deliberation in terms of freedom. I have already dealt with the starting point of freedom as a matter of respecting people's irreconcilable comprehensive doctrines. Regarding the second aspect, deliberation is not seen as a way for citizens to overcome their reasonable differences, or to emancipate themselves from their misconceptions. Rather, it is regarded as a means for coming to some kind of agreement despite enduring differences. A conservative bias can be detected in Rawls' insistence that citizens must refer only to presently accepted beliefs. Public reason is not a means of overcoming prejudices, entrenched meanings, ideologies, or any of the other issues that concern critical theorists. As we saw, Rawls claims that excluding comprehensive views or the whole truth from public reason is a way of respecting each other as reasonable. But this also excludes the possibility of helping one another to overcome our prejudices, misconceptions, or ideological delusions. Reasonableness as a content constraint favors the protection of the negative freedom to determine one's own views over the autonomous, intersubjective formation of those views. ${ }^{33}$

\section{Form reasonableness}

Now distinguish reasonableness of content from the idea of reasonableness of form. This is a distinction between what is said and how it is said. As an example of reasonableness as a constraint on content I have mentioned the Rawlsian idea of the political. As examples of constraints on the form of deliberation we might say that it is unreasonable to use manipulation, deception, and threats. Of course threats concern what is said as well as how it is said. But excluding threats from deliberation does not mean excluding certain kinds of reasons, but avoiding what are not properly reasons. The Rawlsians are concerned with 'the kind of reasons that should be given' in deliberation, ${ }^{34}$ and not merely with the idea that reasons, as opposed to threats, for example, should be given. So by reasonableness of form, then, I am thinking about what it means to distinguish, for instance, between arguing and bargaining. In argumentation, the participants are allowed only to seek to rationally motivate each other, i.e. to make the other agree on the basis of the merits of the 
case and nothing external to it. The only force that is supposed to count in argument is, in Habermas' famous phrase, 'the peculiarly constraintfree force of the better argument'. ${ }^{35}$ Arguing becomes bargaining when the participants start threatening one another or offering one another rewards external to the case at hand. When $A$ bargains with $B, A$ tries to influence $B$ by means of positive or negative sanctions. $A$ is here trying to influence $B$ by controlling his or her situation. By contrast, when $A$ argues with $B, A$ tries to come to an understanding with $B$. $A$ is here trying to rationally motivate $B$, not by controlling her or his situation, but by attempting to affect her or his intentions. ${ }^{36}$ In this case, a reasonableness constraint would be one that required the participants to offer only reasons rather than threats or rewards. ${ }^{37} \mathrm{I}$ am not saying that a deliberative democracy can only accept strict argument as opposed to bargaining, but I am stressing how discussions of this issue differ from discussions of constraints on content of reasons within argument. And restrictions of content and form can be seen as manifesting emphases on different dimensions of freedom, as we shall see below.

The processes of political opinion- and will-formation could never be restricted to rational argumentation - that would overburden citizens and no decisions would be made - but must also include bargaining and voting. ${ }^{38}$ The aspiration for deliberative democrats should be that when bargaining and voting are necessary, the conditions and procedures are fair and have been justified and accepted as such in rational argumentation. ${ }^{39}$ Thus, deliberative processes cannot be reduced to argumentation but the latter is the fundamental form of deliberation.

Although Habermas has carefully distinguished between different forms of communication, ${ }^{40}$ he has not articulated the requirements of using only arguments as a matter of reasonableness or as a virtue. Nevertheless, in the Habermasian framework it would clearly be an advantage if citizens limited themselves to using only arguments, rather than threats or other resources external to the issue under discussion. Still, it is important to see - also in order to understand his view of freedom that Habermas' project never has been to tell people that they ought to argue. Such a moralistic outlook lies far from the idea of a critical theory. ${ }^{41}$ His theories of communicative action, discourse ethics, and deliberative politics have been more concerned with the conditions and procedures of deliberation than with the virtues of the participants. ${ }^{42}$ How, in terms of dimensions of freedom, does the concern with form differ from the concern with content of deliberation? The answer to this question shows an essential and consequential difference between Rawlsians and Habermasians.

A core idea in Habermas is that people interpret their needs and form their identities, desires, and opinions in communication, or intersubjectively. And when this communication is distorted, the processes 
of identity- and opinion-formation do not take place rationally and autonomously. So the concern for the form of communication is a concern that the formation of identities, need-interpretations, interestarticulation, and opinion- and will-formation all happen rationally and autonomously. The dimension of freedom that comes to the fore here is not the right to form one's comprehensive views individually or nonpublicly, as in Rawlsian content reasonableness, but the ideal of forming one's views in communication free from all forces other than that of the better argument. Both these dimensions of freedom can be seen as negative conceptions, since they both protect citizens from something. The constraint on content protects citizens against discussion of their comprehensive views. The constraint on form protects citizens against all forces other than the better argument. But the Habermasian view cannot be purely negative, since we need others to be free. 'Because persons are individuated only by way of socialization, the freedom of one individual cannot be tied to the freedom of everybody else in a purely negative way, through reciprocal restrictions. ${ }^{33}$ The two dimensions can also both be positively formulated. The constraint on content is concerned with the freedom to determine one's own comprehensive views. The constraint on form is concerned with the freedom rationally and intersubjectively to form one's opinion and will; in other words, its positive aim is internal autonomy.

Thus, the Habermasian view shifts the focus away from reasonableness as a virtue of citizens to a concern for the social conditions under which people form their views. We move from using restricting the admissible content of reasons as a screening mechanism to a critique of social conditions and procedures of deliberation. I believe this point relates to Habermas' roots in critical theory and in particular ideology critique and therefore turn to that issue.

\section{Habermas: criticism, not tolerance}

In his early The Structural Transformation of the Public Sphere, Habermas reproaches John Stuart Mill for demanding 'not criticism but tolerance'. ${ }^{4}$ What Mill lacks, according to Habermas, is an idea of a universal interest to which criticism can refer as criterion. It is exactly the search for a way to solve the problem of how a plurality of competing interests could converge in a general interest that has animated Habermas' writings since 1962..$^{45}$ The theories of communicative action and discourse ethics are aimed at discovering a normative potential and a criterion to which we can refer despite our differences. This is not the place to go into the details of these theoretical developments. What interests me is to make explicit Habermas' normative commitments, especially in terms of his 
view of freedom, and show how they contrast with those of Rawlsian models of deliberative democracy.

A main difference between Habermas and the Rawlsians is that Habermas' theory does not stand back from criticizing metaphysical doctrines. Habermas is still interested not merely in tolerance but in criticism: 'Philosophy should not merely accept established convictions but must also be able to judge them by the standards of a rational conception of justice. ${ }^{46}$ This conception of justice, however, is not a substantial one determined by the theoretician or philosopher who then imposes it from without on the citizens as subjects. ${ }^{47}$ Rather, the criticism is aimed at convictions only indirectly; it is primarily focused on procedures and conditions: the procedure of which the convictions are the product and the conditions under which they were formed. But, veritably, it is a conception that must be the product of reason, albeit a procedural reason. This is a central Kantian element in Habermas. Thus, in the preface to Between Facts and Norms, Habermas says that modernity 'depends on a procedural reason, that is, on a reason that puts itself on trial'. ${ }^{48}$ Procedural reason should be distinguished from and substitute for essentialist Platonic reason and natural law - as well as from unreason and relativism. Rawls takes exception to such a view. It is too comprehensive, he thinks, because it criticizes comprehensive views and asks citizens to replace their comprehensive views with procedural reason. ${ }^{49}$ The question is whether deliberative democracy can do without a commitment to procedural reason. I think not.

Consider two important dimensions of freedom involved in Habermas' view of the 1990s when he returns to democratic theory in a comprehensive manner. ${ }^{50}$ First, the reason for criticizing established convictions can be seen as grounded in a concern that the latter, even if citizens see them as their own, are not reflectively and freely endorsed. Such convictions are not freely endorsed when they are not the product of insights gained in free and public deliberation. Secondly, Habermas always connects the idea of criticism with an idea of public autonomy. For criticism to avoid becoming paternalistic or authoritarian, it must be part of and speak to the common exercise of political freedom in processes of public deliberation. Both of these dimensions of freedom are combined in what Habermas admits to be the 'dogmatic core' of his theory: 'the idea of autonomy according to which human beings act as free subjects only insofar as [1] they obey just those laws they give themselves [2] in accordance with insights they have acquired intersubjectively. ${ }^{51}$ In order to be autonomous, citizens must not only give laws to themselves but must do so on the basis of the best available reasons. Rawls' notion of full autonomy, which is a specifically political value, includes the first, but it excludes the second because of his reluctance to criticize comprehensive doctrines. ${ }^{52}$ Thus, we do find an idea of public autonomy in 
Rawls, but it differs from Habermas' view in not being concerned with how citizens come to hold the views that make them support some legal norms and public policies over others. I see this 'how' as a matter of internal autonomy or lack thereof.

Habermas' view is more comprehensive than Rawls' purports to be, because it requires that the laws we give to ourselves must be based on insights that are the product of what we might call comprehensive deliberation, i.e. deliberation that may include all issues. In terms of autonomy, it is more comprehensive because it requires that when citizens assent to a law they do so on the basis of insights gained inpublic deliberation and not merely on the basis of their publicly noncriticizable comprehensive views. But in Habermas, it is only the reasons for supporting laws that are publicly discussed and scrutinized, not citizens' private life-projects. Habermas' theory seeks to be comprehensive only in the sense in which Kant's is thus, and not in the fuller sense of giving answers to what constitutes a good and fulfilling life. ${ }^{53}$

Above, I noted that the focus on ancient versus modern liberties neglects the ideal of internal autonomy. In order to understand the latter dimension of freedom and how it found its way into models of deliberative democracy with roots in the critical theory tradition of the Frankfurt School, I suggest we look more closely at the theory of ideology.

\section{The critique of ideology and internal autonomy}

Recent writings on deliberative democracy have not been particularly concerned with the critique of ideology. ${ }^{54}$ One reason for this can be found in the synthesis between Habermasian and Rawlsian theories of deliberative democracy. The critique of ideology does not sit well with political liberalism. ${ }^{55}$ There are, however, still some strands in later Habermasian writings that reveal the roots in the tradition of ideology critique, though I think critical theorists need to demarcate themselves more strongly from Rawlsian political liberalism than they do. There are some elements of ideology critique that deliberative democrats could abandon only at the cost of blunting its critical edge. And, in particular, the critique of ideology thematizes an important dimension of freedom, which has a tendency to fall out of view in liberal theories, namely the free formation of political opinions or internal autonomy. To make explicit the idea of internal autonomy, I go back to the earlier Habermas as well as to other writings on ideology. It is crucial in light of the concern for multiple dimensions of freedom, however, not to base ideology critique on perfectionism or a conception of the good; rather, it should be based on reasons of justification. The acceptance of ideology critique, moreover, means we must give a stronger weight to political freedom, because we otherwise fall into paternalism. 
Which understanding of freedom does the theory of ideology entail? 56 When we speak about the oppressive effects of ideology, we are concerned not with external but with internal obstacles to emancipation, at least in the first instance. Our lack of freedom when we are ideologically delusioned has not so much to do with the external world (that we cannot do something because others - or nature - prevent us from doing it), as with our own beliefs and desires. Hence, ideology diminishes internal autonomy.

Ideology can block emancipation either because it has the result that we do not believe things should be different than they are or that we do not think they could be different. In the latter case, ideological delusion means 'that the agents' form of consciousness is artificially limited, i.e. that they suffer from restrictions on what they can perceive as real possibilities for themselves' ${ }^{57}$ The first form of ideology makes certain relations and conditions appear legitimate. This might be the most obvious form of ideology. It is the form of ideology that Marxists speak of when they say that bourgeois ideology makes capitalist relations of production appear legitimate. Marx's labor theory of value and exploitation has a critical intent in so far as it shows that the relationship between the bourgeoisie and the proletariat was not a free and equal form of exchange, as it was claimed to be in bourgeois ideology. ${ }^{58}$

Ideologies do not only function by legitimizing certain relationships and institutions but also by reifying them, i.e. by making them seem " "natural" and thus, ineradicable, unavoidable, and unalterable'. ${ }^{59}$ When Habermas in the late 1960s described science and technology as (a new form of) ideology, he saw them as having this second function. He saw science and technology not as explicit forms of legitimation, not as what we might call moral ideologies. They do not - as bourgeois ideology does - include norms and values, which can justify certain developments. Rather, they are precisely characterized by a professed value-freedom, promoted by the epistemological theory of positivism. It is exactly the bracketing of moral questions that makes science an ideology. ${ }^{60}$ This new ideology 'is distinguished from its predecessor in that it severs the criteria for justifying the organization of social life from any normative regulation of interaction, thus depoliticizing them' ${ }^{61}$ This form of ideology still has legitimating power, albeit an implicit one. ${ }^{62}$ No one objects to or questions the natural and inevitable.

'The point of a theory of ideology is that agents are sometimes suffering from a coercion of which they are not immediately aware.'63 As such, it relies on a dimension of freedom hidden to the liberal theorist. Liberalism can be the basis of one form of critique based on its understanding of freedom, namely critique of institutions that rely on direct interference with our actions and choices beyond those that harm others. But this is too limited. Ideology critique with its implied idea of internal autonomy gets at two closely related issues that we cannot get at from 
the perspective of social criticism based on the dimension of negative freedom alone. First, the fact that there are no external constraints on an action is not sufficient for my being free to do it, as I may be prevented from choosing to do it by my form of consciousness, by my constellation of beliefs and desires. ${ }^{64}$ To be free to do what one wants does not cover all dimensions of freedom. If I am not also free to do want what I want, or if my very wants are shaped unfreely, I still lack freedom in the sense of internal autonomy. The person who is ideologically constrained cannot be said to be unfree from the perspective of Hobbes' or Berlin's notion of freedom, since she or he finds no obstacles to doing what she or he wants. ${ }^{65}$ The point of ideology critique is that there is more to be said about freedom, more questions that need to be asked. We want not merely to ask whether there were any external obstacles to an omitted action, such as legal restrictions, but also whether the individual came to his or her conclusions whether to perform the action or not freely. So if a certain group or class of people, for example, does not run for office, we do not merely ask whether there is legal discrimination that prevents them from doing so, but also whether their own self-understanding is freely formed, whether they based their decision (or non-decision) on good reasons. The theory of ideology rejects the answer that if someone does not do something to which there are no external obstacles, then there are no objections in terms of freedom. There is another dimension of freedom we should be concerned with: internal autonomy. ${ }^{66}$

The second aspect made clear by the theory of ideology, while neglected by the negative freedom perspective, is that freedom is not only limited by the interference of others but might be self-imposed. 'The agents in a society impose coercive institutions on themselves by participating in them, accepting them without protest, etc. Simply by acting in an apparently "free" way according to the dictates of their worldpicture, the agents reproduce relations of coercion. ${ }^{67}$ The notion of negative freedom has nothing to say to such situations, because people in a sense are not prevented from doing what they want. They consent to their situation and hence must be free from a liberal perspective. Negative freedom, thus, is not a sufficiently broad conception of freedom for a critical theory; it is only a conception of one dimension of freedom.

The Rawlsian adherence to the negative freedom tradition and its commitment to not criticizing comprehensive doctrines make political liberalism incapable of approaching the dimension of freedom manifest in the theory of ideology. Rawls explicitly rejects the critique of ideology:

We should not readily accuse one another of self- or group-interest, prejudice or bias, and of such deeply entrenched errors as ideological blindness and delusion. Such accusations arouse resentment and hostility, and block the way to reasonable agreement. The disposition to make such accusations without compelling grounds is plainly unreasonable, and often a declaration of intellectual war. ${ }^{68}$ 
By taking this stance, Rawls excludes the possibility of investigating whether reasonable comprehensive doctrines and the overlapping consensus between them could not be such world-views that inadvertently reproduce relations of coercion. If there is no probing of citizens' comprehensive views in deliberation, then there is no non-violent way in which a check may be made whether the policies and institutions they support are defensible. For the sake of stability, Rawls advances what could be seen as a strategy of depoliticization.

We should not disregard Rawls' point that charges of ideological delusion might create resentment, however. Jack Knight and James Johnson are too quick in dismissing Rawls on this issue:

It very plausibly is among the desirable features of democratic deliberation that it allows participants to raise [the possibility that some are deluded by ideology], to challenge those to whom they believe the charge applies, to do so publicly and, thereby, to afford those so challenged to respond. ${ }^{69}$

Knight and Johnson reduce ideology to other forms of error and selfinterest. In the Marxist and critical theory tradition, however, ideology is something more systemic. Not all cases of persons being wrong about what they can get and what they want are cases of ideological delusion. There are many other sorts of mistakes than those caused by ideology. ${ }^{70}$ The critique of ideology is only concerned with beliefs and desires that are systematically distorted by the circumstances under which they are formed. ${ }^{71}$ In the Habermasian version, the concern is systematically distorted communication since it maintains that communication is the processes in which we form our beliefs and desires. ${ }^{72}$ Moreover, ideology critique is not directed immediately at certain people's beliefs but rather at the conditions under which these beliefs are formed and at the general structure of communication. Ideology critique does not need to challenge specific people with being deluded - something Rawls probably is right to say would create resentment and undermine rather than promote deliberation - but intends to suggest that the conditions under which all of us form our beliefs are distorting. That is, it aims to show that there is a problem with the general structure of communication in our society. The connection between ideology critique and deliberation, then, is not that we in deliberation can charge each other with being ideologically deluded (as Knight and Johnson hold), but that we need non-distorted deliberation in order to overcome our ideological one-sidedness.

Moreover, ideology critique rejects the idealistic notion that we can overcome ideology merely through critically discussing it. ${ }^{73}$ Ideologies do not disappear until the power structures that uphold them are dissolved. However, from the perspective of deliberative democracy that I am advancing - as committed to multiple dimensions of freedom - the critique of ideology must begin with critical discussion, but this is a discussion aimed at changing the structures that uphold ideology. 
The problem with ideology is that it excludes certain issues from being publicly discussed at all. The call for a more deliberative democracy on this view is a call for politicization, politicization in the sense of opening up for reflection the practical-moral sides of our relationships and the conditions under which we live. Increased deliberation aimed at overcoming ideology does not require that we question each other's deepest motives. ${ }^{74}$ What matters is that the validity of the beliefs is being probed in a free and non-distorted manner. Thus, we can accept Rawls' statement that it is wrong in public deliberation to charge others with being ideologically deluded. The disagreement with Rawls is that he excludes certain basic questions from reflection and deliberation. If certain issues are not discussed at all, we have no way of knowing if they are valid nor whether they are freely held.

When we contrast the earlier Habermas with Rawls, the former's critique of depoliticization stands out. Habermas' critique of the ideology of science and technology owes much to earlier critical theory, in particular Herbert Marcuse. ${ }^{75}$ The critique of depoliticization is a critique of the way in which moral and political questions are turned into technical ones and of the concomitant idea of decisionism; the belief that moral questions are incapable of truth and hence 'cannot be discussed cogently [but] in the final instance must be decided upon, one way or another'. ${ }^{76}$ Decisionist politics stands, of course, in the sharpest contrast to deliberative politics. Decisionism denies what the idea of public deliberation confirms, that normative questions can be rationally discussed and that some solutions are better than others are.

A main contrast between Habermas' and Rawlsian models of deliberative democracy today concerns whether public deliberation should be concerned with truth-claims. Habermas' insistence on seeing deliberation as about truth and not merely about the politically reasonable could be seen as having its roots in his critique of the depoliticizing tendencies of technocracy and positivism. From the perspective of the early Habermas, the importance of deliberation is exactly that it politicizes or makes the object of reflection what is seen as natural or what is otherwise excluded from questioning. Rawlsian deliberative democracy clearly does not share the ethical decisionism of positivism; nevertheless, by excluding fundamental issues from deliberation, it might have the same depoliticizing effects.

\section{The aim of ideology critique: triggering self-reflection}

From the perspective of deliberative democracy as committed to multiple dimensions of freedom, we should limit the aim of deliberation and critique to what matters for justification of public policies and law, which is not the same as limiting topics that can be discussed. We are concerned only with the free formation of beliefs regarding issues of common 
concern and not with how people form their views of the good life, at least not insofar as the latter can be separated from processes of justification. In Rainer Forst's words, 'Critical theory . . . is a critique of existing "relations of justification" as the presupposition for establishing and developing a justified basic structure of society'. ${ }^{77}$ To Forst's formulation, it should be added that hidden relations of justification of ideological character are included. The critique, then, is not perfectionist in the sense of being concerned with whether people live examined lives and critically scrutinize their private life-projects. It is concerned with people's internal autonomy only insofar as it affects how public policies and laws are justified and legitimized. Of course, there might be (and most likely is) a causal relationship between free formation of opinions in processes of justification of political-moral norms and citizens' views of their own good, but the normative commitment to internal autonomy is independent of such an effect.

We should distinguish between critique being directed at what the ideology says (its content) and how it came into being; that is, between the epistemic properties of its composite beliefs and its genetic properties. ${ }^{78}$ The critical theorist who wants to make a criticism based on the epistemic properties of the ideology alone needs an independent standard, a correct answer, to which he or she can compare the constituent beliefs of the ideology. Such an approach would violate an important dimension of freedom, the freedom of the agents to think for themselves. If, on the other hand, the criticism were directed at the genesis of the ideology alone, it might be asked why it matters how an ideology came into being if its constituent beliefs are correct and do not support oppressive institutions (the genetic fallacy). ${ }^{79}$

In Habermas, we find an approach that combines criticism directed at genesis and at epistemic properties. ${ }^{80}$ It is exactly by - and only by - analyzing how a specific form of legitimation or justification came into being that we can know whether it can be presumed to be right or not. If processes of legitimation are systematically distorted, then their results are ideological and epistemically dubious. 'Ideology on this definition is ... the result of asymmetric communication, where asymmetries can include ones that result from information, power, status and role, and cultural differences. ${ }^{81}$ The critique of ideology is therefore aimed at that which distorts communication. The content or epistemic properties of the beliefs of the addressees, therefore, are not the direct aim of ideology critique. The proceduralism of Habermas' approach entails that we cannot have any rational presumptions about what are true or false beliefs except as results of processes of deliberation free from domination. The advantage of this approach is that the theorist does not and cannot take the paternalistic role of the philosopher expert who comes down from Mount Olympus to tell people what is right or wrong. Rather, what has 
the presumption of being right and wrong must be determined through practices of common deliberation. The weakness of this approach is that we might never get to deliberation free from domination, or at least it is not a reality now. Thus a possibility is to speak of hypothetical deliberation. This is Habermas' approach in Legitimation Crisis, where he says that a social theory critical of ideology "compares normative structures existing at a given time with the hypothetical state of a system of norms formed, ceteris paribus, discursively'. ${ }^{82}$ But this solution cancels the advantages in terms of freedom of the proceduralist approach. If the theorist could know what would result from free deliberation, then there would be no need for actual and common deliberation. ${ }^{83}$ If ideology critique is to be compatible with the normative commitments of deliberative democracy (the multiple dimensions of freedom) and be able to contribute to their realization, it should avoid pre-empting actual processes of deliberation. Instead, it should play the role of provoking such processes of deliberation by initiating processes of self-reflection.

To be true to the normative commitments of deliberative democracy in general and in order to avoid paternalism in particular, it is crucial, then, to distinguish between the theory of ideology as a way of showing people what their real interests are and as a means of triggering selfreflection. ${ }^{84}$ The first view requires that the theorist knows what real interests are from some external point of view and hence is incompatible with the proceduralism that I think should be the core of deliberative democracy and which is the only way to protect the dimension of freedom involved in the right to think for oneself. The second view is compatible with proceduralism and with a conception of freedom that sees freedom as a matter of individuals coming to insights by their own efforts as participants in processes of public deliberation. As James Bohman has argued, critical theorists should participate as critics in the public sphere. The claims they make 'are successful not in so far as they bring agents to particular true insights, but rather in so far as they initiate processes of self-reflection, the outcome of which agents determine for themselves' ${ }^{85}$ Critical theory should not say that people are deluded, but make them consider whether they are so. This is done by provoking them to participate in processes of public deliberation.

Thus, the aim of ideology critique is emancipation from a specific form of oppression and is achieved via processes of self-reflection. ${ }^{86} \mathrm{An}$ important point in this connection is that the first step is not to remove coercion and oppression: for example, an oppressive state and an exploitative market economy. The first step is for people themselves to realize that the present institutions are not in fact in the common interest. ${ }^{87}$ It is only if people themselves realize that their present situation is unjust and then overturn it that this change can happen democratically and in accordance with the deliberative commitment to political freedom. 
A theory of ideology along the lines briefly sketched here should be intimately related to a concern for political freedom; first, because ideology is related to legitimation; second because the critique of ideology to avoid paternalism cannot rely on negative freedom alone but must focus also on the common exercise of political freedom. The critique of ideology shows how we uphold certain institutions with our active support or with mere compliance. One point of the theory of ideology is that political institutions and social relations are upheld by constellations of beliefs and desires - or by certain structures of communication, and not merely by violence. Indeed, successful ideological domination means that there is no need to use violence at all because the subjects accept the structures. And as such, oppression is in a sense self-imposed or at least reproduced by ourselves. Here there is no possible criticism from the perspective of negative freedom and the concomitant consent theory; we need to go deeper, to another dimension of freedom. The question raised from the perspective of the critique of ideology is how political authority legitimizes itself. The critique of ideology is a critique of certain forms of legitimation. In the Habermasian version, it is specifically a critique of forms of legitimation that take place by limiting communication, i.e. by excluding some claims from being discussed. ${ }^{88}$ Processes of legitimation in order to be non-ideological need to be free from domination, and this is exactly how we should define the aim of deliberative democracy. In Bohman's words, 'democracy is also a particular structure of communication'. ${ }^{89}$

It is a crucial lesson - and one sometimes overlooked by its critics - that deliberative democracy is not merely a call for more communication but a call for a particular structure of communication - namely one free from distortion and domination. When the roots in the theory of ideology are forgotten or abandoned, this important point tends to fall out of view. A common misunderstanding of deliberative democracy is that it sees any agreement reached on the basis of talk as good. ${ }^{90} \mathrm{But}$ clearly, language is not only a medium of reaching free agreements; it can also be used as a means of domination, exclusion, and social power. And proponents of deliberative democracy, at least those coming out of the tradition of critical theory, are or should be well aware of this. The way to understand language as a medium of domination is exactly via the critique of ideology. ${ }^{91}$ Part of the misunderstanding - and deliberative democrats themselves are not without fault in this - is that the aim of deliberation is always to go from disagreement to agreement, and that if there is agreement there is no problem. ${ }^{92}$ But if agreement is the product of ideological domination, then the aim of deliberation is to show that the agreement is only apparent or that it is not the product 
of free deliberation. ${ }^{93}$ To see this, deliberative democrats should not forget their roots in critical theory and the importance of the critique of ideology.

The critique of ideology should also be related to political freedom in order to avoid paternalism. In his discussion with Rawls, Habermas writes that philosophy 'must avoid equally the uncritical affirmation of the status quo and the assumption of a paternalistic role'. ${ }^{94}$ The traditional liberal critical standard and solution to the danger of paternalism is negative freedom. We avoid a paternalistic state and paternalistic cocitizens, according to this view, by giving citizens equal rights to determine and live according to their own ideas. But negative freedom is not sufficient when we have become aware of the problem of ideology. In this respect Habermasian critical theory is more ambitious than Rawlsian political liberalism. ${ }^{95}$ It is so because it does not leave people's comprehensive views outside politics or outside political philosophy. It criticizes them. Here we see that Habermas has not left the critique of ideology entirely behind. But for this reason Habermas might also be regarded as in greater danger of succumbing to paternalism than Rawls is.

The difference between critical theory and Rawls is not that the first sees the importance of social circumstances while the other does not. Rawls, of course, is not a libertarian who thinks formal liberties are sufficient. Rawls is also aware that social conditions affect our preferences. ${ }^{96}$ And he advocates giving fair value to political liberties. ${ }^{97}$ But there is an important difference between Rawls' worth of freedom argument and the one regarding internal autonomy. The first is concerned with giving people objectively fair conditions in order to make their formal freedoms worth their nominal value. The second is concerned with self-reflection on the basis of which citizens themselves can overturn oppressive institutions and unjust social conditions. Rawls' perspective is purely external, while the critical theory perspective takes the perspective of a participant and makes the change of circumstances dependent upon that it can be accepted in the exercise of political freedom, i.e. in processes of public deliberation. This latter route is closed to Rawls, because he sees it as a violation of the principle of toleration to discuss people's comprehensive views. He is therefore forced to go directly to implementing social justice. Thus, opposite to what one might expect, it is Rawls who turns out to be the paternalist and not the critical theorist with his or her basis in ideology critique.

Habermas' answer to the problem of paternalism is proceduralism and an emphasis on political freedom. ${ }^{98}$ But Habermas does not mention in this connection the third dimension of freedom, the free formation of one's beliefs and desires that I have stressed. It is possible that Habermas sees this dimension as included in his notion of public autonomy; indeed, it must be. But we need to highlight this dimension of freedom in order 
to make explicit the difference with Rawls. When Habermas and Rawls discuss who best accommodates both ancient and modern liberties, the internal autonomy dimension falls out of view. Now, if Habermas would wish to see internal autonomy as part and parcel of public autonomy, then he should have seen that what distinguishes him and Rawls is not the weight they give to negative and political freedom, respectively, but that they view political autonomy in different ways. And Rawls should have seen the same. The crucial difference from a Rawlsian perspective is not that Habermas gives too much weight to political freedom, but that Habermas sees the free formation of one's comprehensive views (insofar as they affect political legitimation) as part of what the exercise of political freedom entails. I have separated the third dimension of freedom in order to make this clear. But I agree that internal autonomy only matters insofar as it affects processes of legitimation - and not when it bears only on issues of the good life. Internal autonomy should be part of political freedom also in the way that it is only people themselves in the process of deliberation who can determine whether or not something really is in their interest.

\section{Conclusion}

Because of their starting point in the fact of reasonable pluralism and the consequences they draw from it, Rawlsian deliberative democrats undermine the enlightenment and emancipatory potentials of processes of public deliberation. The Rawlsians draw deliberative democracy in an unfortunate uncritical direction and confuse what the potentials of public deliberation are. The one-dimensional concern for accommodation of citizens with different and incompatible comprehensive doctrines excludes the possibility that freedom might be enhanced by critical discussion of fundamental differences in world-views. The importance of the free formation of political opinions, of internal autonomy, falls out of view from the perspective of political liberalism. The content reasonableness required by Rawlsians in the exercise of public reason shows a concern, not with the free and enlightened formation of political opinions, but with protecting citizens from having their fundamental ideas discussed.

If we want to understand deliberative democracy as a critical theory of contemporary society - as I have argued we ought to do - we should resist the synthesis between Rawlsian and Habermasian deliberative democracy. The strength of deliberation is not merely to accommodate and uphold existing differences but to initiate processes of reflection about policies and institutions that are uncritically accepted by most people. Hence, the starting point for deliberative democracy should not be 'the fact of reasonable pluralism' but rather 'the fact of unreflective 
Rostbøll: Emancipation or accommodation

acquiescence'. The aim of public deliberation should not merely be accommodation but emancipation. Rawlsian deliberative democrats are so afraid of offending people that they close off the potential of comprehensive deliberation to achieve its emancipatory aims. People's comprehensive doctrines are sometimes intrinsically linked to their acceptance of injustices in society. The Habermasians, on their side, have followed the liberals too far and forgotten their roots in the critique of ideology and what I have emphasized as a third dimension of freedom, internal autonomy.

University of Copenhagen, Denmark

\section{Notes}

An earlier version of this paper was presented at the annual meeting of the American Political Science Association, Philadelphia, 28-31 August 2003. I would like to thank Elizabeth $\mathrm{H}$. Ellis and Michael Lipscomb for their comments on that occasion. I am also grateful for comments from Jean Cohen, Jon Elster, and Pablo Gilabert.

1 Even though many of the ideas that today are seen as central to deliberative democracy can be found in the earlier works of Habermas and Rawls, not until recently have they both explicitly joined the ranks of adherents. Habermas first develops an explicit theory of deliberative democracy in his Between Facts and Norms, trans. W. Rehg (Cambridge: Polity, 1996[1992]), but as early as 1962, in his The Structural Transformation of the Public Sphere, trans. T. Burger (Cambridge, MA: MIT, 1989), he had brought up central concerns of what later was to be called deliberative democracy, such as publicity, rational argumentation, etc. The theory of communicative action and discourse ethics can also be seen as being prolegomena to the theory of deliberative democracy; see The Theory of Communicative Action, vols I-II, trans. T. McCarthy (Cambridge: Polity Press, 1984, 1987) and 'Discourse Ethics: Notes on a Program of Philosophical Justification', in Moral Consciousness and Communicative Action, trans. C. Lenhardt and S. Weber Nicholsen (Cambridge: Polity Press, 1990). The first time Rawls identifies his idea of public reason as belonging to the theory of deliberative democracy is in 1997, in his 'The Idea of Public Reason Revisited', reprinted in his Collected Papers, ed. S. Freeman (Cambridge, MA: Harvard University Press, 1999), pp. 579f., though he also mentions the relation in 'Reply to Habermas', Journal of Philosophy XCII (1995): 132-80, at 133 n. 1 and $177 \mathrm{f}$.

2 Joshua Cohen's influential 1989 article, 'Deliberation and Democratic Legitimacy', draws heavily on both Rawls and Habermas. (It was reprinted in Deliberative Democracy: Essays on Reason and Democracy, ed. J. Bohman 
and W. Rehg [Cambridge, MA: MIT, 1997].) In his later articles, however, Cohen draws less on Habermas and more on Rawls (who, in his later writings, is in turn influenced by Joshua Cohen). See 'Procedure and Substance in Deliberative Democracy', in ibid. and 'Democracy and Liberty', in Deliberative Democracy, ed. J. Elster (Cambridge: Cambridge University Press, 1998). In his 'On Legitimacy and Political Deliberation', Political Theory 15(3) (1987): 338-68 (347ff.), Bernard Manin, by contrast, sees Rawls of A Theory of Justice (Oxford: Oxford University Press, 1973) as an example of a non-deliberative view, because in the original position there are no differences between the parties and hence no reason for common deliberation.

3 Habermas, 'Reconciliation through the Public Use of Reason', in The Inclusion of the Other: Studies in Political Theory, ed. C. Cronin and P. De Greiff (Cambridge, MA: MIT Press, 1998), p. 50.

4 Rawls is also a neo-Kantian of sorts, but his turn to political liberalism is a turn away from a commitment to Kantian autonomy.

5 J. Donald Moon, 'Rawls and Habermas on Public Reason: Human Rights and Global Justice', Annual Review of Political Science 6 (2003): 257-74, also notes the very different traditions Rawls and Habermas stem from but without discussing their views of freedom.

6 This discussion was commissioned by The Journal of Philosophy and published in vol. XCII (1995).

7 Joshua Cohen also focuses on the relationship between ancient and modern liberties; see 'Procedure and Substance', pp. 409-12.

8 Habermas, 'Reconciliation', pp. 69ff.; “"Reasonable” versus "True,” or the Morality of Worldviews', in The Inclusion of the Other, p. 100f.; Rawls, 'Reply to Habermas', 168f. On this difference between Rawls and Habermas, see also Frank Michelman, 'How Can the People Ever Make the Laws?', in Deliberative Democracy: Essays on Reason and Politics, ed. J. Bohman and W. Rehg (Cambridge, MA: MIT Press, 1997), and Samuel Freeman, 'Deliberative Democracy: a Sympathetic Comment', Philosophy and Public Affairs 29(4) (Fall 2000): 371-418 (413ff.).

9 The most ambitious attempt at such reconciliation is Habermas, Between Facts and Norms. It is also an aspiration for John Rawls; see Political Liberalism (New York: Columbia University Press, 1993), p. 4f.; references to this text will be given in the text as PL; I have used the 1993 edition except for the 'Introduction to the Paperback Edition' of 1996. Joshua Cohen, too, has this aspiration; he makes two quite different arguments for it in 'Deliberation and Democratic Legitimacy' and in 'Procedure and Substance'.

10 Cf. Christian F. Rostbøll, 'Preferences and Paternalism: On Freedom and Deliberative Democracy', Political Theory 33(3) (June 2005): 370-96.

11 Other proponents of deliberative democracy have recently noted and lamented the uncritical direction the theory has taken and urged a return to critical theory. See John S. Dryzek, Deliberative Democracy and Beyond: Liberals, Critics, Contestations (Oxford: Oxford University Press, 2000), pp. 2f., 20ff.; Iris M. Young, Inclusion and Democracy (Oxford: Oxford University Press, 2000), p. 10f. and 'Activist Challenges to Deliberative 
Rostbøll: Emancipation or accommodation

Democracy', Political Theory 29(5) (2001): 670-90; William E. Scheuerman, 'Between Radicalism and Resignation: Democratic Theory in Habermas' Between Facts and Norms', in Habermas: A Critical Reader, ed. P. Dews (Oxford: Blackwell, 1999).

12 I have attempted to develop such a theory of freedom in Christian F. Rostbøll, Deliberative Freedom: Deliberative Democracy as a Critical Theory (Albany, NY: SUNY Press, 2008).

13 Rawls, Political Liberalism, paperback edn (New York: Columbia University Press, 1996), pp. xxxvii-viii. The idea of reasonable pluralism also plays a central role in Joshua Cohen's articles from the 1990s; see, for example, Joshua Cohen, 'Procedure and Substance' and 'Democracy and Liberty'. But 'reasonable pluralism' is absent from Cohen's influential 1989 'Deliberation and Democratic Legitimacy'.

14 Cohen, 'Procedure and Substance', p. 408f.; Cohen, 'Democracy and Liberty', p. 187ff.; Rawls, Political Liberalism, passim.

15 Note that the disagreement is about the reasons behind the norms guiding our common life, not about the norms themselves. Regarding the latter, Rawls believes there can be an overlapping consensus among reasonable comprehensive doctrines. See Political Liberalism, Lecture IV, pp. $133 \mathrm{ff}$.

16 See also Rawls, 'Reply to Habermas', p. 136.

17 As also noted by Habermas, 'Reconciliation', p. 67.

18 William Galston distinguishes Reformation and Enlightenment liberalism, where the former is concerned with diversity and the latter with autonomy. According to Galston's definitions, autonomy is 'linked with the commitment to sustained rational examination of self, other, and social practices'; diversity means 'legitimate differences among individuals and groups over such matters as the nature of the good life, sources of moral authority, reason versus faith, and the like'. William A. Galston, Liberal Pluralism (Cambridge: Cambridge University Press, 2002), p. 21.

19 See also Rawls, 'Public Reason Revisited', p. 611.

20 See also Cohen, 'Democracy and Liberty', pp. $188 \mathrm{ff}$.

21 For Madison's discussion of faction, see Alexander Hamilton, James Madison, and John Jay, Federalist Papers, ed. C. Rossiter (New York: Mentor, 1999), no. 10, esp. p. 46.

22 Rawls, 'Reply to Habermas', p. 145.

23 Though they can do so in the background culture. Criticism of Rawls for wanting to constrain civil society discussions is misdirected since public reason does not apply to what he calls the background culture. Rawls' public forum should not be confused with Habermas' public sphere. See Rawls, 'Reply to Habermas', p. 140, n. 13; Rawls, 'Public Reason Revisited', pp. 575f., 608; Rawls, Political Liberalism, pp. 220, 249; and Charles Larmore, 'Public Reason', in Cambridge Companion to Rawls, ed. S. Freeman (Cambridge: Cambridge University Press, 2003), pp. 381f. On the other hand, this means that Rawls has no theory of deliberation in the informal public sphere, which is a serious shortcoming for a theory of deliberative democracy.

24 The preceding argument borrows from Habermas, "Reasonable” versus "True", pp. 83-5, 93. 


\section{Philosophy \& Social Criticism 34 (7)}

25 Rawls, however, goes beyond the negative freedom tradition by emphasizing the economic conditions that secure 'the worth of freedom'. See below.

26 Similarly, Nadia Urbinati has argued that deliberative practices (and Mill's conception of liberty) cannot be understood in terms of Berlin's theory of two liberties. Urbinati, Mill on Democracy: From the Athenian Polis to Representative Government (Chicago, IL: University of Chicago Press, 2002), pp. 1, 10, 12, $155 \mathrm{ff}$.

27 Cf. Freeman, 'Deliberative Democracy: a Sympathetic Comment', pp. $405 \mathrm{ff}$. For Habermasian criticisms of content reasonableness constraints, see Seyla Benhabib, 'Toward a Deliberative Model of Democratic Legitimacy', in Democracy and Difference: Contesting the Boundaries of the Political, ed. S. Benhabib (Princeton, NJ: Priceton University Press, 1996), pp. 74ff.; Dryzek, Deliberative Democracy and Beyond, pp. 42ff.; Habermas, Between Facts and Norms, p. 308.

28 Rawls, 'Public Reason Revisited', p. 578.

29 ibid.

30 Jack Knight and James Johnson make a similar point; see 'What Sort of Equality Does Deliberative Democracy Require?', in Deliberative Democracy. Essays on Reason and Politics, ed. J. Bohman and W. Rehg (Cambridge, MA: MIT Press, 1997), pp. 286f.

31 Jean-Jacques Rousseau, On the Social Contract, trans. D. A. Cress (Indianapolis, IN: Hackett, 1987), bk IV, ch. 2, p. 82.

32 For a good argument for incorporating self-interests as a legitimate aspect of deliberation, see Jane Mansbridge, 'Practice-Thought-Practice', in Deepening Democracy: Institutional Innovations in Empowered Participatory Governance, ed. A. Fung and E. O. Wright (London: Verso, 2003), pp. 179-88. On how moving from purely self-regarding preferences to generalizable interests involves a process, see Habermas' description of how generalizable interests 'emerge step by step' in 'the course of successively undertaken abstractions'. 'Reconciliation', p. 58; and Manin, who says: 'the structure of the deliberative system usually makes the protagonist strive to enlarge their points of view and propose more and more general positions. There is a sort of competition for generality.' See 'On Legitimacy and Political Deliberation', p. 359.

33 Whether there is a conflict between these two dimensions of freedom is an issue to which I return. It seems Rawls thinks there is, since he wants to protect citizens from the discussion of their comprehensive views in the public forum.

34 Amy Gutmann and Dennis Thompson, Democracy and Disagreement (Cambridge, MA: Belknap Press of Harvard University Press, 1996), p. 52. Or as Rawls puts it, public reason 'is a view about the kind of reasons on which citizens are to rest their political cases in making their political justifications to one another when they support laws and policies that invoke the coercive powers of government concerning fundamental political questions'; 'Public Reason Revisited', p. 603. I would group Gutmann and Thompson as Rawlsian deliberative democrats, but it should be noted that they allow greater inclusion of comprehensive views in public deliberation than Rawls does. On this, see Dennis F. Thompson, 'Public Reason and 
Precluded Reasons', Fordham Law Review 72(5) (April 2004): 2073-88, esp. $2083 f$.

35 Habermas, The Theory of Communicative Action, I, p. 24.

36 Habermas, The Theory of Communicative Action, II, p. 277; Habermas, 'Discourse Ethics', 58; Jean Cohen and Andrew Arato, Civil Society and Political Theory (Cambridge, MA: MIT Press, 1992), p. 486.

37 Habermas, it should be emphasized, would not see a virtue like reasonableness as the solution to the problem of distorted communication; see further below.

38 Jon Elster notes that arguing, bargaining, and voting are the three ways in which decisions can be reached in modern societies. See his 'Introduction', in Deliberative Democracy, ed. J. Elster (Cambridge: Cambridge University Press, 1998), pp. 5f. Others have argued for the inclusion of humor, greetings, testimony, storytelling, and so on, as legitimate parts of the deliberative process. These, however, are not forms of decision-making, though they do affect opinion formation. For alternative forms of communication, see Young, Inclusion and Democracy, ch. 2.

39 Cf. Habermas, Between Facts and Norms, pp. 162-8, esp. pp. $166 f$.

40 The most important work here is still The Theory of Communicative Action, but see also Between Facts and Norms, pp. 151-68, where Habermas makes it clear that deliberative democracy cannot rely on argumentation as the only form of communication, but must allow also, for example, for bargaining. See, in addition, 'Three Normative Models of Democracy', in The Inclusion of the Other, ed. C. Cronin and P. De Greiff (Cambridge, MA: MIT Press, 1998), p. 245: 'The concept of deliberative politics acquires empirical relevance only when we take into account the multiplicity of forms of communication in which a common will is produced, that is, not just ethical self-clarification but also the balancing of interests and compromise, the purposive choice of means, moral justification, and legal consistencytesting.'

41 Cf. Christian F. Rostbøll, 'Dissent, Criticism, and Transformative Political Action in Deliberative Democracy', Critical Review of International Social and Political Philosophy (forthcoming).

42 In Between Facts and Norms, pp. 340-1, Habermas emphasizes that 'one should seek the conditions for a rational political will-formation not only at the individual level of the orientation and decisions of single actors but also at the social level of institutionalized processes of deliberation and decision making'. And in his discussion with Rawls, Habermas proposes 'that philosophy limit itself to the clarification of the moral point of view and the procedure of democratic legitimation, to the analysis of the conditions of rational discourses and negotiations'. 'Reconciliation', p. 72; emphases added.

43 Habermas, "“Reasonable” versus "True", p. 101.

44 Habermas, The Structural Transformation of the Public Sphere, p. 135.

45 Jürgen Habermas, 'Further Reflections on the Public Sphere', in C. Calhoun (ed.) Habermas and the Public Sphere (Cambridge, MA: MIT Press, 1992), pp. $441 \mathrm{ff}$.

46 Habermas, “"Reasonable” versus "True”, p. 97. 
47 For a criticism of philosophers who impose their ideas on citizens from without, see Michael Walzer, 'Philosophy and Democracy', Political Theory 9(3) (1981): 379-99.

48 Habermas, Between Facts and Norms, p. xli.

49 Rawls, 'Reply to Habermas', pp. $135 f$.

50 Habermas has, of course, much to say that relates to democratic theory in his works in the 30 years between The Structural Transformation and Between Facts and Norms, but it is only with the latter work that he develops a comprehensive democratic theory.

51 Habermas, Between Facts and Norms, pp. 445f.

52 Rawls, Political Liberalism, 77ff.

53 Habermas, “"Reasonable" versus "True", pp. 98ff.

54 An exception is James Bohman; see his Public Deliberation (Cambridge, MA: MIT Press, 1996), ch. 5; and "When Water Chokes": Ideology, Communication, and Practical Rationality', Constellations 7(3) (September 2000): 382-92. This lack of concern with ideology is also noted and regretted (but not made good) by Iris Young; see her 'Activist Challenges to Deliberative Democracy', p. 686.

55 Rawls directly rejects that ideology critique has a legitimate role in public deliberation; see below.

56 For a recent article that gives a good, systematic overview of the literature on ideology, see Tommie Shelby, 'Ideology, Racism, and Critical Social Theory', The Philosophical Forum XXXIV (Summer 2003): 153-88. The best book on Habermas and ideology is, to my knowledge, Raymond Geuss, The Idea of a Critical Theory (Cambridge: Cambridge University Press, 1981). I have learned much from Geuss' excellent study and draw upon it in my discussion of ideology below. Geuss notes that ideology critique and critical theory depend 'crucially on a theory of freedom and coercion', p. 78.

57 ibid., 83.

58 Karl Marx, Capital, vol. 1, trans. B. Fowkes (Harmondsworth, Mx: Penguin, 1990); see Part I, ch. 1 for the labor theory of value and Part III on surplus value and exploitation.

59 Shelby, 'Ideology, Racism, and Critical Social Theory', p. 177. On reification, see also Habermas, The Theory of Communicative Action, II, p. 355.

60 See Jürgen Habermas, 'Technology and Science as "Ideology", in Toward a Rational Society (Boston, MA: Beacon Press, 1970), and Jürgen Habermas, Knowledge and Human Interests (Boston, MA: Beacon Press, 1971), p. 303.

61 Habermas, 'Technology and Science as "Ideology"', p. 112.

62 ibid., 105.

63 Geuss, The Idea of a Critical Theory, p. 78.

64 Geuss gives such a definition of ideology as a form of consciousness, The Idea of a Critical Theory, p. 12. Bohman rejects that ideology is 'false consciousness', it is rather 'the result of asymmetric communication'; see “"When Water Chokes", p. 385. But to say what something is the result of is not to give an alternative to what it is. And, as Shelby notes, 'ideologies cannot have their peculiar and profound social impact without being received into the consciousness of human beings'. 'Ideology, Racism, and 
Critical Social Theory', p. 157. Habermas also sees (saw?) ideology as a form of consciousness, 'technocratic consciousness', see 'Technology and Science as "Ideology", p. 107.

65 See Thomas Hobbes, Leviathan (Oxford: Oxford University Press, 1996), ch. XXI and Isaiah Berlin, 'Two Concepts of Liberty', in Four Essays on Liberty (Oxford: Oxford University Press, 1969), pp. $122 \mathrm{ff}$.

66 In her empirical study of town meeting government in 'Selby', Jane Mansbridge found 'the absence of legal barriers leads most Selby citizens to look on participation or nonparticipation as only a matter of choice. Many townspeople believe, for instance, that holding town office depends primarily on one's willingness to take the job.' See Beyond Adversary Democracy (Chicago, IL: University of Chicago Press, 1983), p. 115. Here, of course, there might be a certain freedom ideology at play. Everyone can run for office, so what is there to complain about?

67 Geuss, The Idea of a Critical Theory, p. 60, cf. pp. 58, 74.

68 John Rawls, 'The Domain of the Political and Overlapping Consensus', in Collected Papers, ed. S. Freeman (Cambridge, MA: Harvard University Press, 1999), p. 478.

69 Knight and Johnson, 'What Sort of Equality Does Deliberative Democracy Require?', p. 284.

70 Michael Rosen, 'On Voluntary Servitude and the Theory of Ideology', Constellations 7(3) (2000): 393-407 (393).

71 Shelby gives a helpful list of features that distinguish ideological beliefs from other beliefs; see 'Ideology, Racism, and Critical Social Theory', pp. $158 \mathrm{ff}$.

72 For a recent discussion of this position, see Bohman, “When Water Chokes”, esp. pp. $383 \mathrm{f}$.

73 Shelby, 'Ideology, Racism, and Critical Social Theory', pp. $187 \mathrm{f}$.

74 This is a fear of some political liberals; see J. Donald Moon, Constructing Community: Moral Pluralism and Tragic Conflicts (Princeton, NJ: Princeton University Press, 1993), pp. 91ff.

75 See Herbert Marcuse, One-Dimensional Man: Studies in the Ideology of Advanced Industrial Society (Boston, MA: Beacon Press, 1964).

76 Jürgen Habermas, 'Dogmatism, Reason, and Decision: On Theory and Praxis in Our Scientific Civilization', in Theory and Practice, trans. J. Viertel (Boston, MA: Beacon Press, 1973), p. 265.

77 Rainer Forst, 'Justice, Reason, and Critique: Basic Concepts of Critical Theory', in The Handbook of Critical Theory, ed. D. Rasmussen (Oxford: Blackwell, 1996), p. 158.

78 Cf. Geuss, The Idea of a Critical Theory, pp. 13ff., 26ff. I leave out here Geuss' third possibility, functional properties.

79 On the 'genetic fallacy', see ibid., p. 20.

80 ibid., p. 69.

81 Bohman, “'When Water Chokes”', p. 385.

82 Jürgen Habermas, Legitimation Crisis, trans. T. McCarthy (Boston, MA: Beacon Press, 1975), p. 113.

83 For a good discussion of the issue of hypothetical versus actual deliberation and its relationship to the charge of authoritarianism against Habermasian 
discourse ethics/deliberative democracy, see Cohen and Arato, Civil Society and Political Theory, pp. 360ff.

84 Geuss lists three kinds of statements about self-reflection that can be found in Habermas' writings: '1. Self-reflection "dissolves" a) "self-generated objectivity," and b) "objective illusion." 2. Self-reflection makes the subject aware of its genesis or origin. 3. Self-reflection operates by bringing to consciousness unconscious determinants of action, or consciousness.' See The Idea of a Critical Theory, p. 61 (notes omitted).

85 James Bohman, 'Habermas, Marxism and Social Theory: The Case for Pluralism in Critical Social Science', in Habermas: A Critical Reader, ed. P. Dews (Oxford: Blackwell, 1999), p. 80.

86 In Knowledge and Human Interest, p. 310, Habermas describes selfreflection as an 'emancipatory cognitive interest', which 'releases the subject from dependence on hypostatized powers'.

87 Cf. Geuss, The Idea of a Critical Theory, p. 73.

88 Habermas, Legitimation Crisis, pp. 112f.

89 Bohman, “'When Water Chokes”', p. 387.

90 I think this is true of Adam Przeworski, 'Deliberation and Ideological Domination', in Deliberative Democracy, ed. J. Elster (Cambridge: Cambridge University Press, 1998), p. 140 and Susan Stokes, 'Pathologies of Deliberation', in ibid.

91 Thomas McCarthy, The Critical Theory of Jürgen Habermas (Cambridge, MA: MIT Press, 1978), pp. 182f.; James Bohman, 'Emancipation and Rhetoric: The Perlocutions and Illocutions of the Social Critic', Philosophy and Rhetoric 21 (1988): 185-204 (192); Jay Bernstein, 'Habermas', in Conceptions of Liberty in Political Philosophy, ed. Z. Pelczynski and J. Gray (New York: St Martins Press, 1984), pp. 409ff.

92 For criticisms of deliberative democracy based on this (mis)understanding, see Adam Przeworski, Democracy and the Market: Political and Economic Reform in Eastern Europe and Latin America (New York: Cambridge University Press, 1991), p. 18; and Ian Shapiro, 'Enough of Deliberation: Politics is about Interests and Power', in Deliberative Politics: Essays on Democracy and Disagreement, ed. S. Macedo (New York: Oxford University Press, 1999), pp. 30-2.

93 See Young, Inclusion and Democracy, p. 119, who argues that inclusive deliberation does not necessarily make agreement easier, but that it can show that we were mistaken about something we thought to be a common interest. Nancy Fraser makes a similar argument; see 'Rethinking the Public Sphere: a Contribution to the Critique of Actually Existing Democracy', in Habermas and the Public Sphere, ed. C. Calhoun (Cambridge, MA: MIT Press, 1992), p. 130.

94 Habermas, “"Reasonable" versus "True"', p. 97.

95 In their 1995 discussion, Habermas raised the question of whose theory is most modest, Rawls' or his own; 'Reconciliation', pp. $72 \mathrm{f}$.

96 Rawls, Political Liberalism, p. 269.

97 ibid., pp. 5f., 327.

98 See Habermas, “"Reasonable” versus "True”, p. 95. 